ЧАЕВИЧ Александр Владимирович - доктор политических наук, доцент; профессор кафедры методологии права и юридической коммуникации Юридического института Российского университета транспорта (МИИТ) (127055, Россия, г. Москва, ул. Образцова, 9; chaevich_alex@mail.ru)

\title{
«ЦВЕТНАЯ РЕВОЛЮЦИЯ» В КАЗАХСТАНЕ КАК ОЧЕРЕДНАЯ УГРОЗА НАЦИОНАЛЬНОЙ БЕЗОПАСНОСТИ РОССИИ
}

\begin{abstract}
Аннотация. В статье анализируются события в Республике Казахстан в январе 2022 г., имеющие черты очередной «цветной революции» на постсоветском пространстве и выступающие как угроза национальной безопасности России. Выясняются причины, как внутренние, так и внешние, ставшие источником возникновения кризисной ситуации в Казахстане, которые привели к вооруженному противостоянию и человеческим жертвам. Оценивается роль Организации Договора о коллективной безопасности (ОДКБ) в обеспечении безопасности и стабильности на территории Казахстана. Автор рассматривает влияние событий в Казахстане на обеспечение стабильности на постсоветском пространстве, на защиту национальных интересов России от внешних вызовов и угроз.
\end{abstract}

Ключевые слова: Республика Казахстан, «цветные революции», национализм, экстремизм, Организация Договора о коллективной безопасности (ОДКБ), миротворчество, угрозы национальной безопасности

$\mathrm{H}$ овый, 2022 г. на постсоветском пространстве ознаменовался очередной «цветной революцией», теперь уже в Республике Казахстан. Первоначально мирные экономические протесты граждан стремительно переросли в вооруженное противостояние, нанеся огромный экономический ущерб стране, а главное, привели к многочисленным человеческим жертвам. События в Казахстане, имеющие характерные черты «цветной революции», требуют серьезного анализа, ибо они представляют реальную угрозу и для национальной безопасности России.

Как известно, 25 мая 1992 г. между Российской Федерацией и Республикой Казахстан был подписан Договор о дружбе, сотрудничестве и взаимной помощи ${ }^{1}$. Свои отношения стороны строят как дружественные государства, руководствуясь принципами взаимного уважения государственного суверенитета и территориальной целостности [Богатуров 2011: 423]. Республика Казахстан является членом СНГ, Евразийского экономического союза (ЕАЭС), ОДКБ, ШОС. Пограничная линия, общая для Казахстана и России, составляет 7512,8 км. Казахстан, как и Россия, является многонациональной республикой. Здесь проживают представители 130 наций и народностей. При этом численность казахов составляет 11244 тыс. чел., русских - 3685 тыс. чел. [Самигулин 2015: 37, 38]. Для России, безусловно, небезразлична судьба наших соотечественников. Казахстан имеет и геополитическое значение как важный транспортный узел, напрямую затрагивающий наши национальные интересы. Поэтому трагические события в дружественном нам государстве напрямую влияют и на ситуацию в Российской Федерации.

Есть разные оценки событий, происшедших в январе 2022 г. в Казахстане, принадлежащие как отечественным ученым, государственным и обще-

1 Договор о дружбе, сотрудничестве и взаимной помощи между Российской Федерацией и Республикой Казахстан от 25 мая 1992 года (ратиф. Постановлением Верховного Совета РФ от 16.07.1992 № 3319-1; вст. в силу 09.10.1992). Доступ: http://publication.pravo.gov.ru/ Document/View/0001201602170003 (проверено 29.01.2022). 
ственным деятелям, так и зарубежным. По мнению председателя ЛДПР В.В. Жириновского, следует выделить две причины, которые привели к тому, что граждане Казахстана начали акции протестов. Первая - социальные проблемы в государстве, сильное социальное расслоение в казахстанском обществе, вторая - политические аспекты, связанные с тем, что граждан не устраивала система власти, при которой бывший президент Казахстана Н.А. Назарбаев оставался неформальным главой государства 1 . Российский ученый-востоковед и экономист Е.Я. Сатановский считает, что ключевой негативный фактор событий в Казахстане - внешнее влияние через радикальных боевиков-исламистов, которые прошли специальную подготовку и вступили в вооруженное противостояние с силовиками ${ }^{2}$. По мнению официальных представителей Европейского союза (ЕС), отраженному в официальном заявлении, это мирный протест граждан Казахстана, и власти должны уважать основополагающие права протестующих и выполнять свои международные обязательства ${ }^{3}$.

В целом январские события 2022 г. в Казахстане требуют комплексного анализа как внутренних, так и внешних факторов и причин, приведших к трагическим событиям в дружественном России государстве. Как стало известно из средств массовой информации, первоисточником мирных протестов стало недовольство граждан резким повышением цен на газ на западе страны в городе Жанаозен Мангистауской обл. С 1 января 2022 г. цена за литр сжиженного газа возросла в 2 раза - до 120 тенге (0,27 долл.). Протестующие требовали снизить цену на газ до 60 тенге (0,13 долл.), однако местные органы их требования проигнорировали, да и руководство страны было в целом уверено, что все «само собой рассосется». СМИ Казахстана тоже не уделили этим событиям должного внимания, а эксперты в ходе передач по телевидению приводили в пример другие страны, где после подобных экономических требований протестующие расходились по домам.

Однако эти события стали спусковым крючком, ибо в стране накопилось много социальных проблем, которые негативно сказались на большинстве граждан Казахстана, прежде всего на слабо защищенных слоях населения. За последние годы в целом произошло существенное падение уровня жизни населения. В 2021 г. в Казахстане цены на потребительские товары по официальным данным взлетели на 8,9\%, заметнее всего выросли цены на продовольственные товары - на 11,3\%, что выше, чем в России. В октябре 2021 г. годовой рост потребительских цен на овощи составил $25,5 \%$, цена на мясо выросла на $10,3 \%$, подсолнечного масла - на $56,2 \%$, сахара $-32,1 \%$. В конечном итоге, это привело к резкому росту показателя инфляции в стране 4 .

Сыграла свою роль в протестных выступлениях в Казахстане и демографическая ситуация в стране. В последние десятилетия здесь была достаточно высокая рождаемость, особенно в сельской местности. Сельская молодежь Казахстана, имеющая в основном низкий уровень образования, многие без

\footnotetext{
1 Жириновский выделил политическую и социальную причины протестов в Казахстане. Доступ: https://daily-inform.ru/563162-zhirinovskii-vydelil-politicheskuyu-i-socialnuyuprichiny-protestov-v-kazahstane?utm_source $=$ smi2ex\&utm_medium $=$ exchange\&utm term=44199 (проверено 19.01.2022).

2 Сатановский: боевики-исламисты стоят за массовыми погромами в Казахстане. Доступ: https://riafan.ru/1584164-satanovskii-boeviki-islamisty-stoyat-za-massovymi-pogromami-vkazahstane (проверено 29.01.2022).

3 Евросоюз призвал власти Казахстана уважать право народа на «мирный протест». Доступ: https://topwar.ru/190869-evrosojuz-prizval-vlasti-kazahstana-uvazhat-pravo-narodana-mirnyj-protest.html (проверено 18.01.2022).

4 Итоги 2021: Провалы года. Доступ: https://semey.city/novosti-kazakhstana/45431/ (проверено 21.01.2022).
} 
постоянной работы, стала основной активной протестной массой противостояния.

Бедность, социальное неравенство, коррупция вызвали обоснованное раздражение у большей части населения страны, а рост цен на топливо стал лишь поводом для массового протеста. Стихийный митинг в г. Жанаозене 4 января 2022 г. привел к столкновениям с полицией. Поддержали эти выступления и жители других городов Мангистауской обл. (областной центр Мангистау и Актау) - они перекрыли автомобильные дороги. К ним присоединились жители Алматы.

По предложению президента Казахстана Касым-Жомарт Токаева оперативно создали специальную комиссию, которая, проанализировав ситуацию, отменила повышение цен на топливо, заморозила цены на основные услуги на полгода. Правительство было отправлено в отставку, но эти меры не остановили протестующих.

Президент Казахстана провел кадровые перестановки в силовых структурах и занял пост главы Совета национальной безопасности, который до этого времени занимал первый президент Казахстана Н.А. Назарбаев 1 . Вместе с тем принятые экстренные меры не смогли стабилизировать ситуацию в стране. Город Алматы и другие города оказались беззащитными перед радикальными погромщиками, реальными террористами, которые перемешались с протестующими. Новостные сводки сообщали о некоторых военнослужащих внутренних войск, переходящих на сторону протестующих.

В Казахстане, по заявлению президента К. Токаева, действовали профессионально подготовленные террористы, что говорит о хорошо спланированной террористической угрозе для государства. В соответствии с Уставом ОДКБ президент Казахстана попросил союзников по договору оказать помощь в борьбе против террористических и погромных элементов.

Уже сейчас, располагая определенными сведениями о нынешней ситуации в Казахстане, можно утверждать, что имел место и заговор против действующего президента К. Токаева. 6 января 2022 г. спецслужбы, верные казахскому лидеру, арестовали экс-главу Комитета национальной безопасности (КНБ) (один из «потомков» советского КГБ) Казахстана К. Масимова по обвинению в государственной измене. Он являлся сторонником экс-президента Н.А. Назарбаева и в разное время занимал важные государственные посты в государстве. С 2016 г. К. Масимов являлся председателем КНБ. В КНБ К. Масимов сосредоточил выполнение многих функций, ибо в его подчинении находились пограничные войска, контрразведка, служба внешней разведки. КНБ осуществлял контроль над информационно-коммуникационной системой в государстве, т.е. это был своеобразный супермонстр среди спецслужб ${ }^{2}$. Комитет, возможно, мог покрывать процесс «взращивания боевиков» на территории страны, проникновение представителей иностранных государств экстремистской направленности, в т.ч. и членов нетрадиционных религиозных течений, с целью их участия в госперевороте. Оценка деятельности этой организации будет дана более детально, когда будут полностью расследованы события и факты происшедших событий. Однако уже сейчас можно сказать, что это была и попытка незаконного захвата власти в Казахстане, возможно, и изменения внутреннего и внешнеполитического курса государства.

\footnotetext{
1 Вакцинация и жадность элит как причина революции в Казахстане. Доступ: https://3rm. info/main/87802-poslednee-kazahskoe-preduprezhdenie-putinu-vakcinacija-i-zhadnost-jelitkak-prichina-revoljucii-v-kazahstane.html (проверено 21.01.2022).

2 Политолог назвал участников готовившегося в Казахстане переворота. Доступ: https:// lenta.ru/news/2022/01/08/kazakh_knb/ (проверено 19.01.2022).
} 
Власти государства, по утверждению президента Казахстана, «проспали» эту самую подготовку. Вместе с тем о такой опасности руководство государств Центральной Азии предупреждали заранее еще летом 2021 г., когда Соединенные Штаты в спешке бежали из Афганистана, оставляя десятки тысяч радикалов, воспитанных ими же, а те переместились через границу соседних государств в качестве беженцев. Боевики постепенно растворились в таджикском, киргизском, казахском обществе, ведя свою подрывную работу, превращаясь в так называемые спящие ячейки. Экстремисты были отлично вооружены и организованы. Применялась известная тактика нападения на правоохранителей и военных организованными «пятерками», осуществлялось показательное обезглавливание своих противников. Надо отдать должное тому, что боевики грамотно атаковали стратегически важные объекты аэропорт Алматы, воинские части, информационные центры и другие важные государственные объекты.

Противостоять погромщикам и террористам силовые структуры Казахстана самостоятельно не смогли, т.к. они в ходе беспорядков подверглись и внешней агрессии со стороны террористов. Поэтому президент Казахстана в соответствии со ст. 4 Устава ОДКБ попросил союзников оказать помощь стране в борьбе против деструктивных элементов. Благодаря слаженным действиям государств - членов ОДКБ ситуацию в Казахстане удалось в целом стабилизировать. Миротворческий контингент в Казахстане изначально был направлен на ограниченный период времени и после выполнения возложенных на него функций по стабилизации ситуации в стране был возвращен в места постоянной дислокации своих государств.

Президент РФ В.В. Путин назвал миротворческую операцию исключительно своевременной и легитимной. ОДКБ в случае с Казахстаном показала на деле свой потенциал, способность действовать быстро, решительно и эффективно. Страны ОДКБ показали, что не позволят раскачивать ситуацию у себя дома и реализовать сценарии «цветных революций» ${ }^{1}$.

В целом уже сейчас можно сделать предварительные выводы по событиям в Казахстане, имеющим черты так называемых цветных революций.

Очередная «цветная революция» на постсоветском пространстве потерпела неудачу. В 2021 г. провалилась попытка государственного переворота в Белоруссии, в 2022 г. уже в Казахстане подобные действия тоже потерпели неудачу. Внешние силы стремятся сформировать пояс нестабильности по периметру границ России, создать реальную угрозу национальной безопасности нашему государству. Однако Российская Федерация, наоборот, укрепила свои позиции на постсоветском пространстве, обеспечив лояльность определенной части политической элиты Казахстана по отношению к России.

Целесообразно сделать выводы и из внутриполитической ситуации в самом Казахстане. Непростая социальная обстановка в государстве, бедность значительной части населения страны, особенно среди молодежи и сельских жителей, резкое социальное неравенство, коррупция, имеющая массовый характер, стали причиной многочисленных выступлений граждан Казахстана. Выводы из этих событий в том, что касается социальной обстановки в стране, должны сделать и сами государства - участники ОДКБ, чтобы уже не задействовать силы миротворцев в своих государствах, когда возникнет ситуация, подобная казахстанской.

Трансформация политической власти в Республике Казахстан оказалась

1 Путин: миротворческий контингент будет находиться в Казахстане ограниченный период. Доступ: https://news.mail.ru/politics/49533547/?frommail=1 (проверено 20.01.2022). 
не вполне эффективной. Фактически сложилось своеобразное двоевластие в управлении государством. Президент Казахстана К. Токаев не обладал реальной политической властью, ибо бывший президент Н. Назарбаев возглавляя Совет безопасности, фактически осуществлял руководство силовыми структурами, которые оказались не готовыми к противостоянию протестующим, а иногда и просто переходили на их сторону. Первый президент Казахстана Н. Назарбаев действительно являлся наиболее талантливым и мудрым руководителем за последние десятилетия на постсоветском пространстве, внес большой вклад в становление суверенного Казахстана. Его заслуги объективно значимы как для страны, так и для интеграционных процессов на постсоветском пространстве. Однако внесение изменений в Конституцию Казахстана, принятую 30 августа 1995 г. на всенародном референдуме, признание Н.А. Назарбаева Елбасы, т.е. пожизненным лидером нации, установка в стране его монументов, переименование столицы Астаны в Нур-Султан имели негативный оттенок. Все это не могло вызвать уважение у здравомыслящей части населения страны, и особенно среди молодого поколения. Поэтому не случайно одним из ключевых лозунгов протестующих был: «старик, уходи», а монументы первому президенту Казахстана были демонтированы варварским путем. Это привело к определенному расколу политических элит общества и стало одной из причин нестабильности в государстве. Еще раз стало очевидным, что сменяемость власти является актуальной для всех государств, выбравших демократический путь развития.

Казахстан - это сложное государство по этническому, национальному и религиозному составу. Руководство Казахстана не принимало действенные меры против национализма, который имеет давние исторические корни. Как известно, еще в бытность СССР, в 1986 г., также проходили массовые выступления в Алма-Ате под националистическими лозунгами. Колонну демонстрантов, направлявшихся 17 декабря 1986 г. в центр города, возглавлял председатель правительства Казахстана Н.А. Назарбаев [Островский 2011: 126]. Более чем через 35 лет подобные события вернулись бумерангом в современный Казахстан.

Серьезные изменения должны произойти и во внешнеполитическом курсе Казахстана. Выступая за интеграцию на постсоветском пространстве, он реально придерживался принципа «многовекторности», ориентируясь на западные государства. Поэтому не случайно инвесторы из западных государств имели приоритет при приватизации крупнейших производственных предприятий Казахстана.

На территории Казахстана зарегистрированы 22000 неправительственных организаций (НПО), из них действующих - 16 000. В стране работает Фонд Сорос-Казахстан. По линии этого фонда с 1975 по 2013 г. более 2000 студентов Казахстана прошли обучение за границей ${ }^{1}$. И все это тоже не прошло бесследно.

Очередная «цветная революция» в Казахстане непосредственно оказала влияние и на ситуацию в Российской Федерации, на ее национальную безопасность. Нестабильность, вооруженное противостояние в дружественном нам государстве, имеющем протяженную границу с Россией, является вызовом и внешней угрозой нашей безопасности. Поэтому военная сила остается важным фактором противостояния так называемым цветным революциям, а

\footnotetext{
1 НПО и НКО Казахстана. Доступ: https://tjournal.ru/u/415960-sayat/443557-npo-i-nkokazahstana (проверено 21.01.2022).
} 
ОДКБ показала свою эффективность в поддержании стабильности на постсоветском пространстве.

\title{
Список литературы
}

Богатуров А.Д. 2011. Международные отношения в Центральной Азии: события и документы. М.: Аспект Пресс. 548 с.

Островский А.В. 2011. Глупость или измена? Расследование гибели СССР. М.: Крымский мост-9Д. 863 с.

Самигулин В.К. 2015. Государственное устройство современного Казахстана: опыт сравнительно-правового анализа. - Проблемы востоковедения. № 2(68). C. $36-41$.

CHAEVICH Aleksandr Viktorovich, Dr.Sci. (Pol.Sci.), Associate Professor; Professor of the Chair of Methodology of Law and Legal Communication, Law Institute, Russian University of Transport (MIIT) (bld. 9, 9 Obraztsova St, Moscow, Russia, 127055; chaevich_alex@mail.ru)

\section{THE COLOR REVOLUTION IN KAZAKHSTAN AS ANOTHER THREAT TO RUSSIA'S NATIONAL SECURITY}

\begin{abstract}
The article analyzes the events in the Republic of Kazakhstan in January 2022, which have the features of another color revolution in the post-Soviet space, and as a threat to Russia's national security. The author investigates the reasons, both internal and external, that became the source of the crisis in Kazakhstan, which led to armed confrontation and human casualties. The paper assesses the role of the Collective Security Treaty Organization (CSTO) in ensuring security and stability on the territory of Kazakhstan. The author examines the impact of events in Kazakhstan on ensuring stability in the post-Soviet space and on protecting Russia's national interests from external challenges and threats.
\end{abstract}

Keywords: Republic of Kazakhstan, color revolutions, nationalism, extremism, Collective Security Treaty Organization (CSTO), peacemaking, threats to national security 